\title{
Kronik
}

\section{Det svære, nye lederskab}

\author{
Ole Fogh Kirkeby
}

S iden år 2000 er der sket meget på det danske arbejdsmarked. For det første nærmer vi os fuld beskæftigelse, og dermed afspejles det epokegørende i kapitalismens tohundredeårige historie, at efterspørgslen på arbejdskraft overgår udbuddet for de fleste fags og professioners vedkommende. For det andet stiger den forholdsmæssige andel af immaterielt arbejde på det manuelles bekostning, den meget brede, og upræcise, betegnelse 'vidensarbejde' er uden tvivl i stærk vækst, dels fordi $R \& D$ (Research and development) ikke længere kun foregår i separate afdelinger i virksomhederne, men bliver en del af arbejdets sociale karakter; dels fordi arbejdsfunktionernes kommunikative sider får større og større indflydelse og dermed det eksperimenterende, improviserende, forklarende og formidlende moment. IT-mediet opfordrer per se til denne udvikling, da informationsbehandling er en kommunikativ aktivitet, der forudsætter en mere uformel relation til viden.

Den eksplosive vækst i HR-afdelinger, også i det offentlige, på personalefunktionens bekostning, dokumenterer, at arbejdskraften er en ressource, der spildes, hvis den ikke får de rette betingelser for at udfolde sig. Næsten absurd bliver den arbejdsgiver-ængstelse for de dyre kapitalanlæg, der allerede i 30'erne og for alvor i 60'erne og fremefter, førte til blødere management-strategier, nu transfor- meret til en intens omhu for arbejdskraftens potentialer for at forhindre, at human-kapital går til spilde, dels i produktionsprocessen selv, dels i manglende fastholdelse og i umuligheden for at rekruttere den arbejdskraft, der vil gøre organisationen fuldt funktionsdygtig. Arbejdskraften er stadig en vare, men en vare, der må konsumeres med en blanding af den nænsomhed, man nærer for giffengodet, og den nidkærhed, hvormed man fortærer det dyrekøbte til sidste krumme.

Løsningen har været uddelegering af kompetencer og ansvar primært gennem organisationsændringer, indførelse af projektgrupper og teams i alle typer af arbejdsprocesser og skabelse af individuelle anerkendelses- og evalueringssystemer, lønforskelle, uddannelses- og udviklingstilbud samt frynsegoder.

Den store opgave i det sidste årti har da været at gøre arbejdskraften lige så afhængig af organisationen, som organisationen må sande, at den er af arbejdskraften.

En afgørende faktor kommer her til: Den vægt på personlig myndighed, udfoldelse og frihed, der er produktet af socialstatens socialiseringsformer fra førskolen til universitetet, samt en voldsom nedtrapning af de klassiske partsmodsætninger på arbejdsmarkedet.

De private og offentlige arbejdsgivere møder i dag en arbejdskraft, der er formet til at stille forventninger til arbejdspladsen 
fra meningsfuldhed over bæredygtighed til social ansvarlighed. Den dialogiske kultur, der er skabt i uddannelsessystemet, og som i arbejdsvirkeligheden har manifesteret sig som fokusering på konsensus, stiller organisationen og lederen overfor en ny situation. Ikke blot er et meget bredt interessent-begreb blevet styrende for den private organisations opfattelse af sin omverden (hensynet til beboere i berørt lokalområder, garanti for ordentlige produktions- og eksistensvilkår for underleverandører i den tredje verden og hele den medieskabte offentlighed herunder de frygtede firmafokuserede blogs), men også, og især, af sine medarbejdere.

Det store problem er her, at meget få virksomheder, og ikke engang længere etaten, kan møde disse spændinger på basis af en funktionel organisationskultur. Personalestyrelsen slår om sig med opfordringer til at give medarbejderne taletid, men det er pludselig ikke længere givet, hvad man skal tale om. De offentlige arbejdspladsers rationalitet er med strukturreformen lagt i stræk mellem et kategorisk effektivitets-imperativ på den ene side og et hypotetisk imperativ om kvalitet af ydelserne på den anden forbundet med en mere eller mindre seriøs invitation af borgeren til medbestemmelse og medskabelse af sit eget offentlige forbrug og sine egne ydelser og aktiviteter. Borgeren er samtidig defineret som skizofren, fanget mellem identiteterne 'forbruger' og 'statsborger'; i egenskab af den første kan (og bør?) han vælge frit på alle hylder; i egenskab af den anden er han ansvarlig for sit eget træk på de fælles ressourcer; og lidelsen forstærkes af den erodering af selve begrebet om det offentlige, som udliciteringspolitikken giver. Disse bevægelser har deres sande spejlbillede i det private erhvervslivs fokus på brugerbaseret innovation, hvor forbrugerens engagement i egen nytteoptimering skal resultere i produktskabelse og effektivisering: I dag skal forbrugeren tænke 'lean lykke' på virksomhedens vegne og forære den resultatet af dette arbejde med livskvalitet til producenterne.

Disse spændinger giver sig markant udslag i vores oplevelse af tid. Som vidensarbejdere, servicearbejdere og producenter skal vi spare tid på at skabe produkter og tjenester, der kan give konsumenter og borgere tid til at konsumere de ydelser, som de arbejdende netop som borgere og konsumenter ikke har tid til at udnytte. De aktive skal med andre ord spare så meget tid på at producere, at de ikke længere selv har tid til at modtage deres egne ydelser og bruge deres egne produkter - og de passive har ikke den tid, der kræves til at udnytte tidsbesparelsen, for de har tid til overflod, men ingen penge. Vi er på arbejde, når vi har fri, vi er konsumtionsarbejdere; og når vi virkelig er på arbejde, skal vi lade som om vi kan have fri, så er vi arbejdskonsumenter.

Ledelsen i det private og i det offentlige står derfor på en uriaspost. For lederen skal på den ene side knytte medarbejderen til organisationen uden at have en solidarisk og loyal arbejdsethos at falde tilbage på og heller ikke længere en specifik fag- og professionskultur at appellere til, og samtidig skal han opløse organisationens grænser, både mod interessenterne udenfor og mod medarbejdernes behov - det sidste for ikke at skrotte deres potentialer.

Nyere bidrag til en tegning af status quo fra grænselandet mellem filosofi og sociologi, der, som italieneren Lazzaratos Foucault-inspirerede arbejder (se fx Negri et al. 1998), bestemmer den nye vidensarbejder ud fra forestillingen om, at virksomheden er en 'verden', som medarbejderen skal være medskaber af, således at ledelse handler om at usurpere dennes liv, lidenskab og intellektuelle kunnen, fordi virksomheden ikke producerer genstande, men betydning - Lazzaratos koncept om at arbejde er ved at blive immaterielt. 
Dette er åbenlyst overdrevet, for så vidt hovedparten af konsumtionsvarer ikke adskiller sig nævneværdigt med henblik på kvalitet, når bortses fra de store økologiske segmenter. Samtidig er medarbejderen udmærket klar over, at han ikke tilhører virksomheden på samme måde, som funktionærer, mellemledere og højere ledere gjorde det tidligere. Han har nemlig ikke længere nogen forpligtelse til loyalitet. Man kan her sige, at solidaritet og loyalitet hører sammen i en kompleks relation. Der kan knyttes loyalitetsbånd på tværs af horisontal solidaritet i organisationen, og hierarkier har altid benyttet denne mulighed, men samtidig udgør solidariteten i alle dens aspekter (faglig, professionel, fagpolitisk, lokal, kønslig, etc.) basis for en virksomhedskultur, der overhovedet kan fokusere på loyalitet. I det øjeblik solidariteten hos den enkelte ligger i forholdet til hans eget cv, er loyalitet reduceret til et rent strategisk anliggende.

Ledere ser sig således næsten skakmatte overfor organisationens og deres eget behov $\mathrm{i}$ forhold til at kunne regne med et fungerende fællesskab på den ene side og de individualiseringsstrategier, som de selv dagligt forstærker, og her bakket gevaldigt op af medarbejderne selv, på den anden. Organisationer er ikke længere mål i sig selv, ikke engang for topledere og departementschefer, men kun midler. I den forstand er arbejdskraften atter blevet samlere og jægere på jagt efter position, giffengoder og arbejdsmening.

Den jagt, som vi nu er vidne til på arbejdsmarkedet, er mere en jagt på den mest gunstige identitet end en jagt på identiteten selv - hvor den sidste jagt kunne imødekommes af stærke, sociale fællesskaber med tilhørende hierarkier i organisationerne.

Der er en umiskendelig parallel-bevægelse mellem udviklingen i parforholdet og udviklingen i arbejdsforholdet. Begge kendetegnes af kravet om indfrielse og imøde- kommelse af passion og varer kun passionen ud.

I den vesteuropæiske tradition har fornuft været modgiften mod passion, for alene fornuften kan styre lidenskaberne. Organisationer har hidtil været behersket af fornuften, eller som det hedder på det latinske forlæg, 'ratio'. Lederne og deres organisation må være fornuftige. Det betyder, at organisationens mål må være klare, målbare som resultater, tilgængelige for evaluering, altså må der kunne konstrueres en objektiv, nøgtern vurdering af midlers relevans. Men i passionen er midlet ofte selve målet.

Passionen må altså underordnes fornuften, men så snart der kræves meget af fornuften hos de enkelte individer, kan passionen ikke undværes. Når passionen da bliver stueren kaldes den 'engagement', 'commitment' og 'entusiasme'.

Men der er flere slags fornuft. Den strategisk-instrumentale fornuft mestrer vi alle i dette samfund. Den passionerede fornuft køber organisationerne sig i stigende grad til. Men den normative, eller værdiorienterede, fornuft derimod, den, der har med grundholdninger, eksistens og liv at gøre, den dybest set 'praktiske fornuft', kan let blive selvrådig, ja, kættersk. Alligevel er det den, der sætter betingelserne for alle andre fornuftsformer, fordi det er i forhold til den, at vi får identitet, mening og livsglæde.

I den strategisk-instrumentale fornufts regi vil arbejdsrelationen være en 'transaktion' baseret på et lige bytte af fordele og ulemper omkring en historisk differentieret artikulation af interesser på mange niveauer af kapaciteter. Under den værdiorienterede fornufts regime vil transaktionsbegrebet let blive truet i sin logik, fordi det drejer sig om at handle af overbevisning og ud fra hensynet til andre. Sagen og mennesket er i centrum. Eksistentielle krav kan ikke afvejes mod løn, avancement og frynsegoder, hvis de er stærke nok. 
Historisk kender vi den værdiorienterede fornufts virke fra de bevægelser, der voksede op omkring religiøse og politiske ideologier, og herfra har virksomhederne overtaget deres begreber om vision og mission. Men problemet er, at hvis passionen ikke er outreret eller destruktiv, men rettet mod indholdet af det liv, man har, så kan den blive farlig for den eksisterende samfundsorden. Så tager arbejdskraften sabbatår, og topdirektøren går på deltid eller stopper, når han er fyrre. Lysten vil evighed, og mennesker, der kan få frihed, vil have mere af den.

Det problem, som lederen står overfor lige nu, er, at den eneste strategi, der kan forene lidenskaben for at have et ordentligt liv med det at arbejde (i et overflodssamfund), er - som Søren Kierkegaard så ofte citeres for - 'at leve for en idé'. Lederen skal med andre ord gøre den instrumentelle fornufts helligdom, organisationen, til en ideologisk bevægelse. Men enhver bevægelse kræver en sag, og den kræver menings-koder. Dette gælder også for det offentlige, der i stigende grad mangler begge dele.

Enhver sag er altid blevet spredt fra mund til mund og gennem koder, der udgjorde dens forankring i netop dens perspektiv på 'sandheden'. At sprede et budskab fra mund til mund kræver budskabets betydning og talens intensitet, forkyndelse altså. Den, der udbreder sagen, skal selv tro på den. Det er ingen tilfældighed, at 'tro' og 'tillid' hedder det samme på græsk (pistis), for den, der vil få andre til at tro på sin sag, må have deres tillid. Tillid forudsætter intimitet (og alle 'ny management'-buzzword'ene: Anerkendelse, omsorg, empati...), og ledelse gennem gensidig tillid er i ordets fulde betydning en intimteknologi, fordi den både er overgribende og omfavnende.

At lede er at hverve proselytter. Men det ord, som lederen forkynder, må ikke være i uoverensstemmelse med den strategisk-instrumentale rationalitet. Det må være båret af en argumentatorisk logik, der i sidste instans kan begrunde, at medarbejderens omvendelse er til hans eget bedste.

Således bliver ledelse pædagogisk og terapeutisk. Intimteknologierne må (som nævnt) operere omkring kommunikative parametre som anerkendelse, tillid, empati og sympati, basisholdninger og omsorgen for medarbejderens indre univers. Lederen må igen og igen fortælle medarbejderen, hvor god han er, fordi han arbejder på netop denne virksomhed, og hvor god virksomheden er, fordi han arbejder på den.

Men dette krav til lederens pædagogiske evner bakkes altid i baghånden op af den forudsætning, at medarbejderen kun er på virksomheden, så længe han er god. Intet har ændret sig, hvad dette sidste vilkår angår, tværtimod.

Det, der er nyt ved lederens praksis, er, at han i langt højere grad end tidligere går tæt på medarbejderen som person. Det gør han ved at tage ansvaret på sig for, at medarbejderen hele tiden bliver bedre. Og det gør han ved at vide meget mere om medarbejderen, end ledere tidligere gjorde. Dette gælder hele hierarkiet, men denne opgave bliver lige nu i stigende grad en del af mellemlederens opgaveportefølje. Han må vide, hvor meget bedre den enkelte medarbejder ville kunne blive og stå inde for, at det effektueres.

Til denne opgave er der udviklet mange teknikker, som vel generelt kan kaldes 'dialogisk ledelse'. Den intimteknologi, der lige nu begynder at dukke op overalt, kaldes ledelsesbaseret 'coaching'. Begrebet er afskyeligt, fordi det etymologisk har med transport og fragtning at gøre, og fordi dets nyere rødder er amerikansk sportskultur tilsat en god portion new age, psykodynamisk terapi og totalitære hjernevask-teknikker. Coaching har eksisteret længe under alle de former, hvor nogen retviser og rådgiver andre, og har været brugt i organisationer i stigende grad gennem de sidste ti år, men 
hovedsageligt varetaget af interne og eksterne konsulenter. $\mathrm{Nu}$ er tiden inde til, at det bliver lederens opgave.

Problemet er, at coaching dækker over fremvæksten af en helt ny, manipulativ form for dialogisk kultur i virksomhederne, hvor personen ikke konfronteres som medarbejder, men som individualitet. Dette måtte jo komme, for så vidt medarbejderfunktionerne ikke ligger fast, for så vidt talent og kunnen er en ressource, og fordi kompetencer spiller mellem det reelle og virtuelle: Du kan ikke nøjes med at kunne det, du kan, men du må kunne det, du skal kunne i morgen.

Det intrikate er, at dialogisk ledelse som seriøst gensidighedsprincip for meningsudveksling kommer medarbejderens frihedstrang i møde, fordi en voksende, dialogisk kultur må orientere sig mod legitimation af beslutninger, store som små, og mod personlig tillid, anerkendelse og gensidig forståelse. Når dialogisk ledelse da bliver ledelsesbaseret coaching - og inden for en kort årrække er alle ledere formodentligt 'coachende ledere' - så formaliseres dialogen. Men den formaliseres ikke nødvendigvis symmetrisk, for den inddrager medarbejderens intimere rum, og dens logik handler om at artikulere, hvad medarbejderen kan gøre for en virksomhed, der er i den position, alle modsatte påstande til trods, at kunne sætte betingelserne for, hvordan den enkelte udlever og udleverer sig selv.

Mange medarbejdere ønsker coaching, dels fordi det opleves som et privilegium, en anerkendelse og en mulighed for at sætte sit eget mål af frihed i centrum, og dermed fanges de i en frihedens fælde skabt af vore demokratisk-dialogiske idealer.

I en vis forstand kan ledelsesbaseret coaching opfattes som en samtale med en parterapeut, hvor klienten selv er gift med terapeuten. Kun i de tilfælde, hvor medarbejderen accepterer coachens dagsorden, koder og værdier, kan samtalen give mulighed for at medarbejderen kan italesætte sine egne behov. Under skriftet diskuterer man kun religiøse spørgsmål under den forudsætning, at man har accepteret institutionen. Man kan ikke stille sig udenfor, men vil altid være en troende eller en frafalden. Den eneste anerkendelse, der gives, er syndsforladelse.

$\mathrm{Nu}$ vil man kunne indvende, at mange coaches behandler problemer i den enkeltes liv, som denne selv følger påtrængende og måske står magtesløse overfor. Og der findes uden tvivl coaches, der vil deres klient det bedste, og som også lykkes med det, selv sub specie aeternitatis, altså ud fra klientens eget udsagn. Men i en organisatorisk kontekst bliver coaching uvægerligt udtagning af stikprøver på hin enkeltes vej. Det skyldes, at ingen organisationer $\mathrm{i}$ nogen fornuftig mening længere kan have en egentlig sag, endsige en stærk ideologi, således at ingen ledere kan regne med, at proselytterne også er troende i morgen. For der er ingenting at tro på.

Med mindre lederen har mod til at konfrontere sine egne værdier med medarbejderens og hertil inddrage og konfrontere organisationens, bliver coaching en raffineret, quasi-humaniserende måde at manifestere magt, alene fordi der i coachingens pas de deux ikke eksisterer nogen habermask bedrearguments-logik. Der er simpelthen ikke noget pragmatisk kriterium for, at et argument er bedre end det andet bortset fra, at der er mere magt bag det ene end bag det andet.

I den forstand kunne man sige, at coaching i virkeligheden er en måde, hvorpå ledelse og medarbejdere hyppigt, og i ransagelsens og selvransagelsens ånd, kan tage de gensidige transaktionsomkostninger op til forhandling og revision ved at artikulere ulemper og fordele.

Måske vil virkningen af ledelsesbaseret coaching da på længere sigt blive organi- 
sationens opløsning, fordi ledelsen ikke længere bliver i stand til at argumentere for transaktionsomkostningernes retfærdighed, ja for selve perspektivets relevans på den strategisk-instrumentale fornufts principper: Det er umuligt at finde ud af, hvad hver part faktisk bidrager med og ønsker at bidrage med, fordi produktivitet bliver - så at sige - 'så relationsbetinget' og 'situationel', at den bliver uoverskuelig.

Men man skal alligevel ikke undervurdere dialogens civilisationsskabende kraft. Dialogen som form indeholder et ideal om symmetri, også selvom den ikke i de enkelte tilfælde kan levere en sej logik, der tvinger de enkelte dialoger ud over deres indbyggede, kontekstuelle og konkrete begrænsninger. Hvis man inviterer medarbejdere til noget, der på overfladen fremstår som et forum, hvor de kan artikulere deres egen, oplyste egeninteresse, så kan de jo ende med at gøre det - især hvis deres stilling på arbejdsmarkedet giver dem bedre og bedre kort på hånden. Når den dag kommer, hvor den coachede kan stille sin kompetences magt bag spørgsmålet: 'Hvad kan virksomheden gøre for mig', så bliver ledelsesbaseret coaching til en pool for den refleksive praksis. Fra dette perspektiv kan den anden fornuft komme til udtryk, den værdiorienterede, fordi dialogerne kan begynde at udfoldes på dens betingelser.

Princippet for den dialog, hvis mål $o g$ midler er at konfrontere den enkelte med de væsentlige holdninger og værdier i sit liv, og i livet, er udviklet i den klassiske, græske disciplin, 'protreptikken', 'kunsten at anspore og vende et menneske mod det betydningsfulde i dets liv'. Protreptikken kendetegnes ved at forudsætte, at dialog og magt hører sammen; den udvikles nemlig på de græske 'executive academies' for topledere og kaldes 'at mildne tyrannen' eller 'fyrstespejlet' og senere 'kongens vej'. Skriftlige og mundtlige appeller til magthaveren om at styre og udvikle sig selv etisk for sin egen, undersåtternes og samfundets skyld vælder frem i renæssance, barok og oplysningstid, hvor biskoppen af Paris, opdrageren af Ludvig d. XIV's barnebarn, Fénelon, skriver sin bog om Mentor, Telemachos' eventyr (1699) ${ }^{1}$, der skulle blive 1800-tallets mest genoptrykte - og koste ham hans karriere.

Den mulighed, at coaching tages ud af transaktions-regimet og i stedet bliver et altafgørende moment i en fælles eksistentiel dannelsesvej er ikke utænkelig, hvis arbejdskraftens indflydelse fortsat stiger hvilket vidensarbejde og små årgange tyder på. For coaching må for ikke at fremstå som en hyper-manipulativ intimteknologi opløses til fordel for en dialog, der tematiserer samtalens institutionelle asymmetrier og dermed de reelle muligheder for gensidighed i lyset af det fælles projekt, at gøre værdier klare og virkelige: Vort liv.

Det er ikke utænkeligt, at dialogen kan sættes i et formelt regi (i begyndelsen), hvor den forvandles til et centrum i organisationer, hvor de eksistentielle problemer, der i stigende grad presser sig gennem oplevelsesøkonomiens og den overfladiske politiks fernis, kan være et direkte tema. For det er faktisk muligt at diskutere eksistentielle og humanistiske værdier selv i funktionelle og ultrapragmatiske omgivelser - kirken, og de politiske partier er opbygget herpå, al totalitær sindelagskontrol til trods.

I den protreptiske dialog vendes et menneske mod det væsentlige i sit liv, men det kan kun ske, hvis den, der bidrager til denne omvending, selv både har gennemgået og løbende gennemgår den. I virkeligheden gentages transaktions-figurens pragmatiske balance-model på et andet plan: Det eksistentielle. Her kan vi da netop forestille os, at et nyt fællesskab vil kunne vokse frem, og en ny 'general intelligence' - Marx' begreb fra 'Grundrisse' - der som meta-platform for praksis er det sted, hvorfra samfundets 
historisk konkrete sum af kunnen, viden og kompetencer fordeles på individer og orga- nisationer, altså på liv i og udenfor arbejdet, i en ny retfærdigheds ånd.

\section{NOTER}

1 Fénelon fremstiller her Mentor som hovedpersonen, en viis, retfærdighedssøgende, der fremhæver individets autonomi og rettigheder - hvor Mentor i Odysseen er en perifær og nærmest utiltalende person. Fénelon forvises på grund af denne bog fra hoffet til sit biskopi i Cambray. Det er fra Fénelon vor positive opfattelse af begrebet 'mentor' stammer.

\section{Referencer}

Negri, A., Maurizio Lazzarato \& Paulo Virno (1998): Umherschweifende Produzenten - Immaterielle Arbeit und Subversion, Berlin, Id-Verlag.
Fenelon, F. (1699) : Les Aventures de Télémaque, fils d'Ulysse, findes på nettet http:// fr.wikisource.org/wiki/Les_Aventures_de_ T\%C3\%A91\%C3\%A9maque.

Ole Fogh Kirkeby er idéhistoriker, dr.phil. og professor ved Institut for Ledelse, Politik og Filosofi, CBS.

e-mail: ofk.lpf@cbs.dk 